\title{
Epipodium Morphology of Prisogaster niger (Mollusca: Vetigastropoda): Revealing Potential Autapomorphies of Diagnostic Value for the Prisogasterinae
}

\author{
Morfología del Epipodio de Prisogaster niger (Mollusca: Vetigastropoda): \\ Revelando Autapomorfías Potenciales de Valor Diagnóstico para Prisogasterinae \\ "Gonzalo A. Collado; *Marco A. Méndez \& **Donald I. Brown
}

COLLADO, G. A.; MÉNDEZ, M. A. \& BROWN, D. I. Epipodium morphology of Prisogaster niger (Mollusca: Vetigastropoda): revealing potential autapomorphies of diagnostic value for the Prisogasterinae. Int. J. Morphol., 30(2):541-545, 2012.

SUMMARY: In this work the epipodium morphology of the marine snail Prisogaster niger is described. In this gastropods the epipodium includes a complex of structures among which the neck lobes, epipodial ridge, epipodial tentacles and epipodial papillae constitute the most remarkable characters. Although these features are commonly found among trochoidean taxa, the observation of the epipodium, compared with the literature, revealed potential autapomorphic characters of diagnostic value for the genus and the subfamily Prisogasterinae, like epipodial lamellae and epipodial tuft.

KEY WORDS: Gastropoda; Turbinidae; Epipodial organs; Morphological characters.

\section{INTRODUCTION}

Prisogaster niger (Wood, 1828) is a common marine snail found along the southwest coast of South America from Paita, Perú, to the Straits of Magellan, Chile (Marincovich, 1973; Osorio et al., 1979; Ramírez, 1981; Alamo $\&$ Valdivieso, 1987). The species has ecological importance in rocky shore communities considering its role as a grazer of algal communities (Vásquez \& Vega, 2004) and being prey for higher vertebrates (Sabat et al., 2003). The species is diocious, the gonad in males is whitish in colour while in females is green (unpublished data from the authors). The spermatozoon is of the primitive (Franzén, 1955) or "aquaspermatozoon" type (Jamieson, 1987), typical of species that release their gametes into the surrounding aquatic environment (Collado et al., 2011).

From the taxonomic point of view, the higher systematics of the genus Prisogaster Mörch, 1850 has been complicated. The genus has been considered a member of the family Phasianellidae (Thiele, 1929; Wenz, 1938) and Turbininae (Robertson, 1958; Knight et al., 1960; Ramírez) more Prisogasterinae (Hickman \& McLean, 1990) within the family Turbinidae sensu lato. More recently, molecular data have contributed to resolve the systematic position of Prisogaster-Prisogasterinae with de redefinition of the family Turbinidae (Williams \& Ozawa, 2006; Williams et al., 2008).

The epipodium, a complex of sensory structures located on the dorsal portion of the foot under the shell margin of the vetigastropods (Cox, 1962; Crisp, 1981), has been used for taxonomic and systematic purposes in the group (Hickman \& McLean; Geiger, 1999; Collado, 2008; Collado et al., 2012). Although the composition of the epipodium varies among authors, we follow Hickman \& McLean that consider it composed of epipodial and cephalic tentacles, left neck lobe, right neck lobe, epipodial papillae, cephalic lappets, right/left subocular peduncles and suboptic and postoptic tentacles.

The aim of the present paper is to describe in detail the macroscopic morphology of the epipodium of $P$. niger. Hickman \& McLean performed observations of the epipodium of this gastropod, but there are still morphological details of the complex unknow in this species.

Laboratorio de Genética y Evolución, Departamento de Ciencias Ecológicas, Facultad de Ciencias, Universidad de Chile, Las Palmeras 3425, Santiago, Chile.

** Laboratorio de Biología de la Reproducción y del Desarrollo, Departamento de Biología y Ciencias Ambientales, Universidad de Valparaíso, Gran Bretaña 1111, Valparaíso, Chile. 


\section{MATERIAL AND METHOD}

Mature adult individuals of $P$. niger were collected

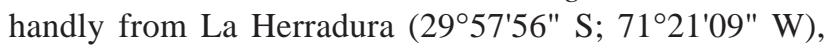
Región de Coquimbo, northern Chile. After collection, ten adult specimens were placed in a narcotizing solution mixture made of seawater and $10 \%$ magnesium chloride prepared with distilled water (Pantín, 1967). Placement of the specimens in the foot-up position in the narcotizing solution provoked extension of the foot and the epipodial organs as the snails tried to right themselves. The snails eventually becoming narcotized with foot and epipodium in an extended position. Following a $30 \mathrm{~min}$ period of narcotization, the specimens were frozen within the narcotizing solution, removed from shell and dissected in a stereoscopic microscope. Voucher adult specimens were preserved in $70 \%$ ethanol and deposited in the Museo Nacional de Historia Natural de Chile, registration number MNHNCL 7615-7617.

\section{RESULTS}

The epipodium of $P$. niger is shown in the Figure 1 (A, B) and Figure 2 (A-O). The cephalic tentacles and cephalic lappets are located on the upper part of the head and are black in colour. External to these structures are found the ocular peduncles, each supporting an eye at the tip. The cephalic tentacles are extensible, and arise from the body wall between the cephalic lappets and the ocular peduncles. The cephalic lappets are thin structures, triangular in form, with the base wider. The neck lobes arise on both sides of the mid-anterior portion of the body. These structures extend posteriorly from the base of each ocular peduncle, are black

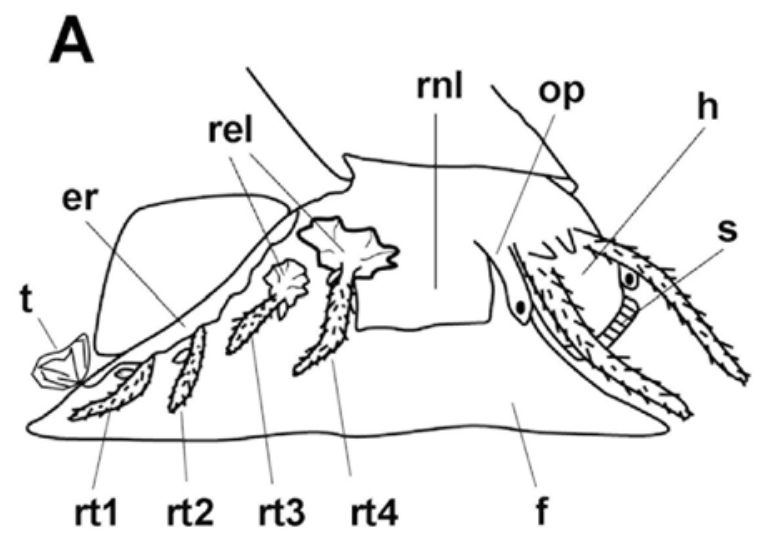

and terminate in the region where the first epipodial tentacle arises. The margin of the neck left lobe is digitiform, bearing tentacles of different length. The margin of the right lobe is smooth, and has a fold on its inner surface which subdivides it into two areas, the posterior wider.

Four epipodial tentacles are extended posteriorly from each side of the snail, each bearing one basal epipodial papilla. The first epipodial tentacle on the right side arises in the area where the right neck lobe terminates. It is remarkable that from the posterior border of the base of this tentacle arises an epipodial laminar structure that we named "epipodial lamina". This thin flaps of tissue extends to the upper border of the foot, close to the operculum. The second right epipodial tentacle is located in the mid-upper region of the foot and also shows a lamina on the border of its base, although this is less developed than that of the first epipodial tentacle. On the left side of the snail, the first epipodial tentacle arises in the region where the left neck lobe terminates. This tentacle lacks of epipodial lamina, but develops one minute basal epipodial tentacle. The second left epipodial tentacle is located in the mid-upper region of the foot and also develops a epipodial lamina around of its base. On both sides of the snail, the third and fourth epipodial tentacles are located on the ventral surface of the epipodial ridge. The epipodial ridge arises in the mid-posterior zone of the snail, and extends to the posterior region of the foot, it is black in colour ventrally and able to expand in width to give a fan-like appearance. This organ is white-greyish in the dorsal side under the operculum. At the posterior end of the snail, over the foot in central position, is developed a conspicuous epipodial structure that we named "epipodial tuft", an extension of the tissue arisen from the epipodial ridge. This structure is black in colour externally, and white internally.

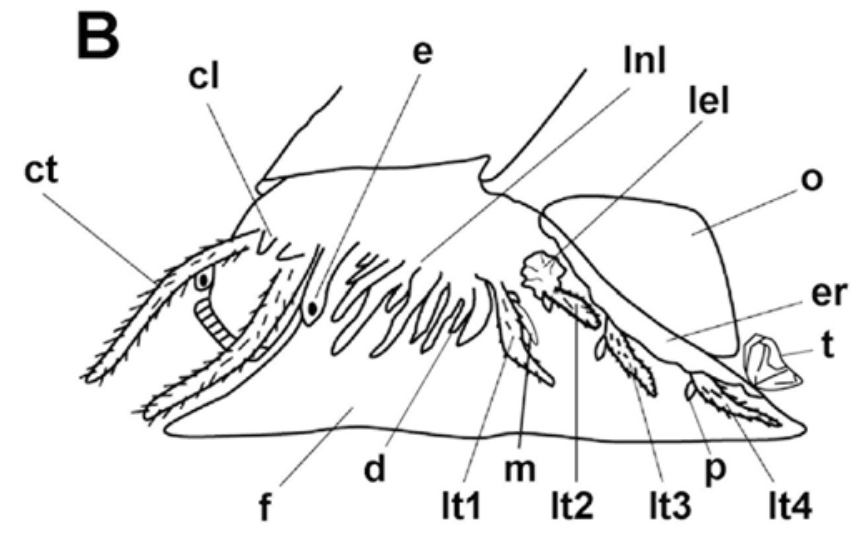

Fig. 1. Drawing of the external anatomy of a relaxed specimen of Prisogaster niger showing epipodial characters from the right (A) and the left side (B), respectively. cl cephalic lappets, ct cephalic tentacle, $d$ dendriform tentacle, e eye, er epipodial ridge, $f$ foot, $h$ head, lel left epipodial lamina, lt1-4 left epipodial tentacles one to four, f foot, h head, lnl left neck lobe, m minute basal epipodial tentacle, o operculum, op ocular peduncle, $\mathrm{p}$ basal epipodial papillae, rel right epipodial lamina, rnl right neck lobe, rt1-4 right epipodial tentacles one to four, s snout, t tuft, y eye. 

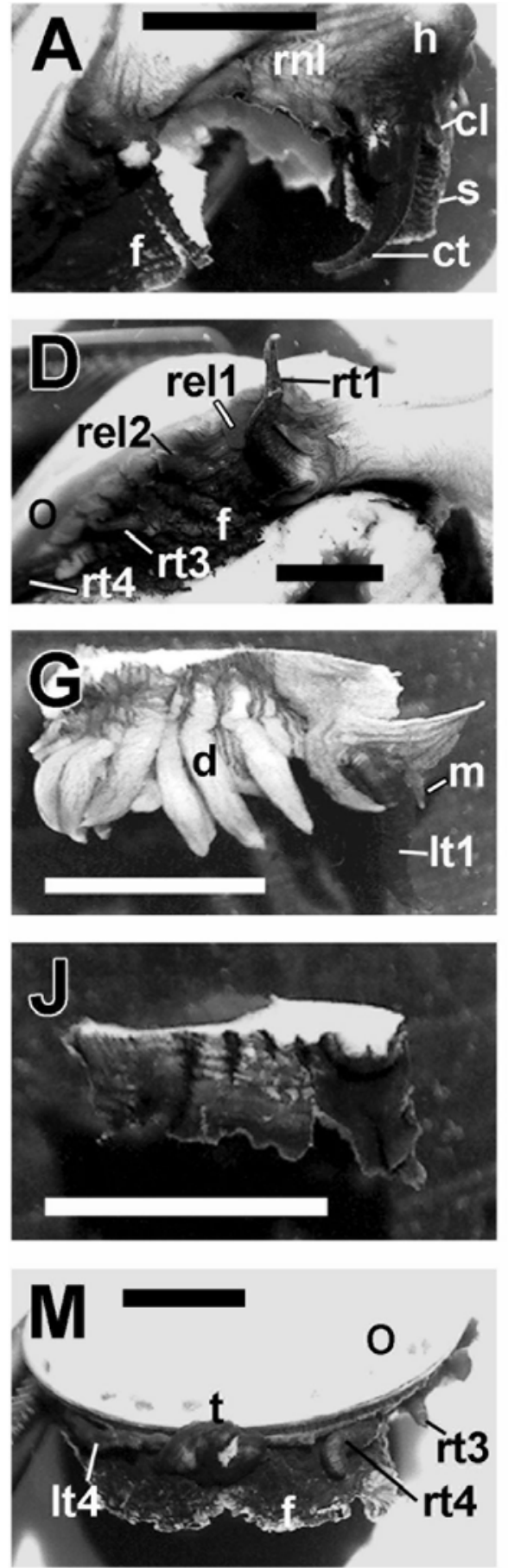
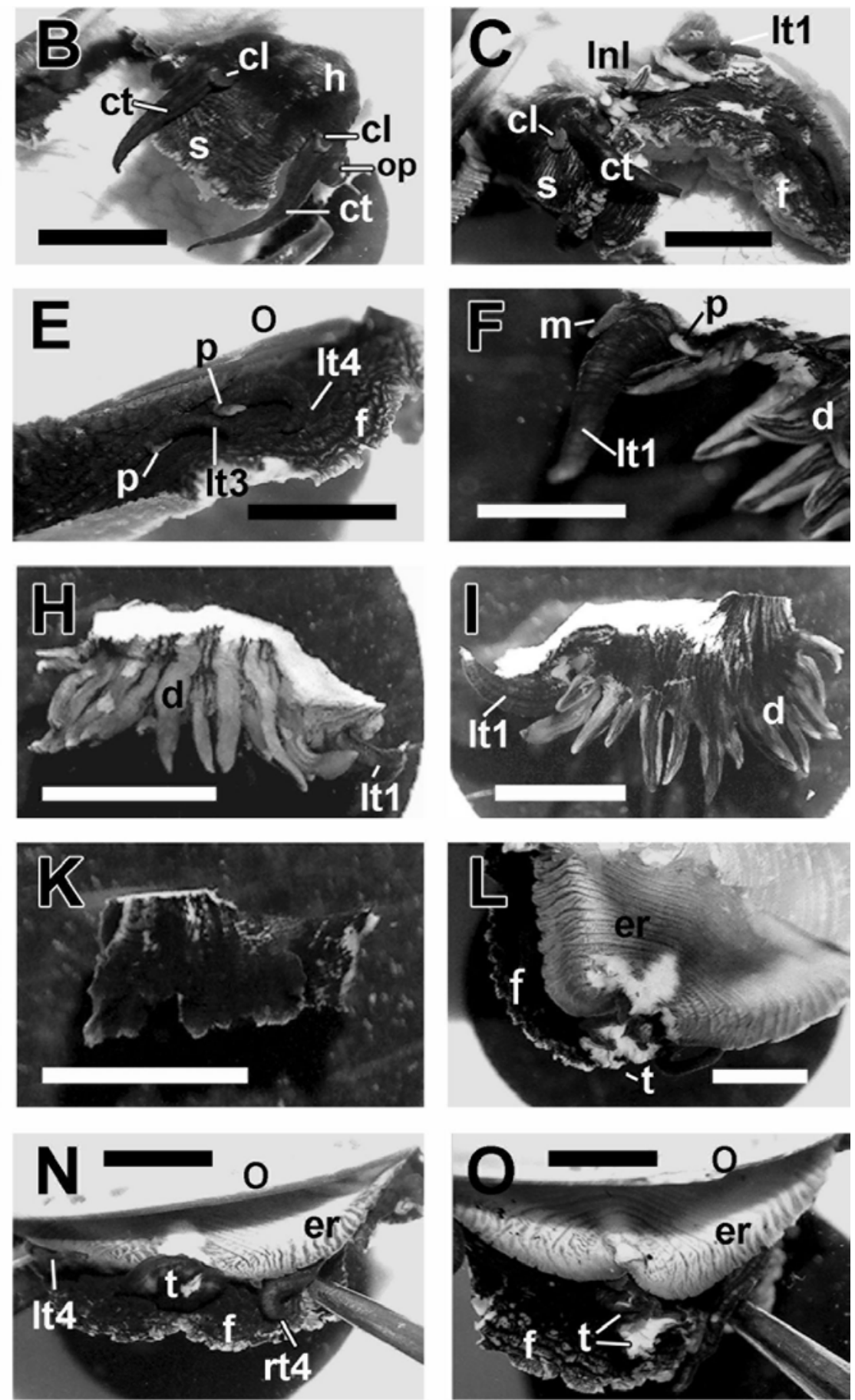

Fig. 2. Epipodial characters of Prisogaster niger seen in specimens with the shell removed. A: Photograph showing the right side of a snail. B: Snail in frontal view. C: Photograph showing the left side of a snail. D: Medial portion of the right side of a snail. E: Posteriormedial portion of the left side of a snail. F: Anterior portion of the left neck lobe showing the epipodial tentacle, the minute basal epipodial tentacle and the basal epipodial papilla. G: Left neck lobe isolated in external view. H: Left neck lobe isolated in external view from a second snail. I: Left neck lobe isolated seen from inside. J: Right neck lobe isolated in external view. K: Right neck lobe isolated seen from inside. L: Dorsal view of the epipodial ridge; the operculum was removed to see the organ. M-O: Snail in posterior view showing the foot, operculum and epipodial tuft. In figure $\mathrm{N}$ and $\mathrm{O}$ the operculum was raised. cl cephalic lappets, ct cephalic tentacle, $\mathrm{d}$ dendriform tentacle, er epipodial ridge, $\mathrm{f}$ foot, $\mathrm{h}$ head, lnl left neck lobe, lt1, 3, 4 left epipodial tentacles one, three and four, $\mathrm{m}$ minute basal epipodial tentacle, o operculum, op ocular peduncle, p basal epipodial papilla, rel1-2 right epipodial lamina, rnl right neck lobe, rt1, 3, 4 right epipodial tentacles one, three and four, s snout, $\mathrm{t}$ tuft. Scale bars: $\mathrm{F}=2 \mathrm{~mm}$, all the rest $3 \mathrm{~mm}$. 


\section{DISCUSSION}

A molecular multilocus analyses of several trochoideans taxa carried out by Williams \& Ozawa and Williams et al. that included DNA sequences of $P$. niger, the only living representative of the subfamily Prisogasterinae (DeVries, 2006), revealed that this subfamily is undoubtedly a member of the family Turbinidae sensu stricto. This hypothesis was recently supported by the study of Collado et al. using the spermatozoon ultrastructure of $P$. niger.

The trochoid epipodium is mainly sensory in function (Crisp). Macdonald \& Maino (1964) suggested that the epipodial tentacles of Tegula funebralis were similar in structure to the cephalic tentacles with a function evidently tactile and probably olfactory. In our laboratory aquaria we observed undulatory movements of both types of tentacle. As the animals moved, the epipodial and cephalic tentacles became actively elongated, frequently touching a solid substrate, suggesting a tactile function. The neck lobes of the trochaceans serve to direct the inhalant (left) and exhalant (right) currents in and out of the mantle cavity (Hickman \& McLean). It has been suggested that in T. funebralis the function of the neck lobes was the removal of waste particles expelled from the mantle cavity (Macdonald \& Maino), although this was not observed in the present study. The epipodial papillae of the trochoids bear a small central depression, from which arise a small tuft of cilia (Crisp), suggesting a sensory function. The ocular peduncles and the epipodial ridge are highly innervated regions, and bear many cilia. The epipodial ridge is highly sensitive to objects with which it came in contact (Crisp), and this is the case of $P$. niger.

Considering the subfamily Turbinidae sensu stricto (after Williams et al.), the epipodium morphology has been described in members of the subfamily Tegulinae, Skeneinae, Margaritinae, Prisogasterinae and Turbininae (Macdonald \& Maino; Hickman \& McLean; Collado; Collado et al., 2012; present study). The epipodium morphology of $P$. niger is similar to those found in representatives of the subfamily Turbininae and Tegulinae (see Hickman \& McLean; Collado; Collado et al., 2012). Hickman \& McLean recognized a close relationship between Prisogasterinae and the Tegulinae based on elaborations of the left neck-lobe of the epipodium, among other features, and we confirmed this suggestion in the present study. The cephalic lappets, however, are less developed in the Prisogasterinae than the Tegulinae, being similar to some members of the Turbininae. Others strange mixture of derived and primitive characters are found among Prisogasterinae, Turbininae and the Tegulinae
(Hickman \& McLean). Molecular analyses carried out by Williams et al. clarified the relationships. These authors inferred that Prisogasterinae is more closely related to the Turbininae than any others turbinid, and they form a clade. Additionally, within the Turbinidae sensu stricto, Prisogasterinae and Turbininae are the only two subfamilies that produce calcareous opercula (Williams et al.) and have a remarkably similar spermatozoon (Collado et al., 2011).

According to Hickman \& McLean, the subfamily Prisogasterinae has convergently developed a number of turbinine characters, including the incomplete peristome, paucispiral operculum and cephalic lappets. Additionally, these authors estimated that Prisogaster lacks of several radular characters, pseudoproboscis and bicarinate juvenil shell that are present in the turbinine. The sister group relationships between Prisogasterinae and Turbininae recovered by Williams et al. offers a different interpretation in the sense that homoplastic features could represent sinapomorphic characters. Similarly, the absence of characters described for Prisogaster could be due to a loss of features, or reversions, a possibility suggested by Hickman \& McLean, but improbably for them. On the other hand, the absence of characters described for Prisogaster could be considered autapomorphic characters of the turbinine representatives.

Hickman \& McLean erected the subfamily Prisogasterinae based on the following characters of $P$. niger: "Peristome interrupted. Operculum with a thick, convex exterior calcareous pad. Ctenidium bipectinate with long dorsal afferent membrane. Left neck lobe digitate, small cephalic lappets present, lip split midventrally, but lacking pseudoproboscis". The laminar structures associated with the first and second right epipodial tentacles and with the second left epipodial tentacle of $P$. niger described in the present study are potential unique derived character states of aditional diagnostic value for the genus and the subfamily Prisogasterinae. The minute tentacle situated in the base of the first left epipodial tentacle and the epipodial tuft found at the posterior end of the snail also represent potential autapomorphic features that are unique to the Prisogasterinae. Additional characters for the genus and subfamily have been obtained from the operculum, columella and spermatozoon morphology (DeVries; Collado et al., 2011).

\section{ACKNOWLEDGEMENTS}

This contribution was partially funded by the Departamento de Postgrado y Postítulo of the Universidad de Chile: Fellowship No PG/01/2003 to G.A.C. 
COLLADO, G. A.; MÉNDEZ, M. A. \& BROWN, D. I. Morfología del epipodio de Prisogaster niger (Mollusca: Vetigastropoda): revelando autapomorfías potenciales de valor diagnóstico para Prisogasterinae. Int. J. Morphol., 30(2):541-545, 2012.

RESUMEN: En este trabajo se describe la morfología del epipodio del caracol marino Prisogaster niger. En esta especie el epipodio está conformado por un complejo de estructuras entre las cuales los lóbulos del cuello, rebordes epipodiales, tentáculos epipodiales y papilas epipodiales constituyen conspicuos caracteres. El estudio de la morfología del epipodio reveló potenciales autapomorfías de valor diagnóstico para la subfamilia Prisogasterinae.

PALABRAS CLAVE: Gastropoda; Turbinidae; Órganos epipodiales; Caracteres morfológicos.

\section{REFERENCES}

Alamo, V. \& Valdivieso, V. Lista sistemática de moluscos marinos del Perú. Callao, Perú, Instituto del Mar del Perú, Boletín Volumen extraordinario, 1987. p.205.

Collado, G. A. Significancia taxonómica del complejo epipodial en especies sudamericanas del género Tegula Lesson, 1835 (Mollusca: Vetigastropoda). Ami. Moll., 16:14-9, 2008.

Collado, G. A.; Correa, C. L.; Méndez, M. A. \& Brown, D. I. Spermatozoon ultrastructure of Prisogaster niger (Wood, 1828) (Mollusca: Vetigastropoda): supporting affinities between Prisogasterinae and Turbininae. Zool. Stud., 50(6):773-9, 2011.

Collado, G. A.; Méndez, M. A.; Brown, D. I. \& Pérez-Schultheiss, J. Phylogenetic analyses and redescription of Tegula ignota (Mollusca: Vetigastropoda). J. Mar. Biol. Ass. U.K., doi:10.1017/ S0025315411002098, 2012.

Cox, K. W. California abalones, family Haliotidae. Calif. Dept. Fish Game, Fish Bull., 118:1-133, 1962.

Crisp, M. Epithelial sensory structures of Trochids. J. Mar. Biol. Ass. U.K., 61:95-106, 1981

DeVries, T. J. The Neogene history of Prisogaster Mörch, 1850 (Gastropoda: Turbinidae) in South America. The Nautilus, 120(4):139-49, 2006.

Franzén, A. Comparative morphological investigations into the spermiogenesis among Mollusca. Zool. Bidr. Upps., 30:339-456, 1955.

Geiger, D. L. A total evidence cladistics analysis of the family Haliotidae (Gastropoda: Vetigastropoda). Ph.D. Thesis, Los Angeles, University of Southern California, 1999.

Hickman, C. \& McLean, J. Systematic revision and suprageneric classification of trochacean gastropods. Nat. Hist. Mus. LA County Sci. Ser., 35:1-169, 1990.

Jamieson, B. G. M. A biological classification of sperm types, with special reference to annelids and molluscs, and an example of spermiocladistics. In: Mohri, H. (Eds). New horizons in sperm cell research. Tokyo, Japanese Science Society Press, 1987. pp.311-32.

Knight, J. B.; Cox, L. R.; Keen, A. M.; Batten, R. L.; Yochelson, E. L. \& Robertson, R. Systematic descriptions (Archaeogastropoda). In: Moore,
R. C. (Eds.). Treatise on invertebrate paleontology. Part I. Mollusca. Lawrence, Geological Society of America and Kansas University Press, 1960. pp.169-310.

Macdonald, J. \& Maino, C. Observations on the epipodium, digestive tract, coelomic derivatives, and nervous system of the trochid gastropod Tegula funebralis. The Veliger 6 (supplement):50-5, 1964.

Marincovich, L. Intertidal mollusk of Iquique, Chile. Nat. Hist. Mus. LA County Sci. Ser., 16:1-49, 1973.

Mörch, O. A. L. Catalogus conchyliorum quae reliquit C.P. Kierulf. Copenhagen, Hafniae dividenda, 1850. pp.1-34.

Osorio, C.; Atria, J. \& Mann, S. Moluscos marinos de importancia económica en Chile. Biol. Pesq., 11:3-47, 1979.

Pantín, C. Técnicas microscópicas para zoólogos. Leon, España, Editorial Academia, 1967. p.90.

Ramírez, J. Moluscos de Chile. 1. Archaeogastropoda. Santiago, Museo Nacional de Historia Natural, 1981. pp.1-149.

Robertson, R. The family Phasianellidae in the western Atlanctic. Johnsonia, 3:245-83, 1958.

Sabat, P.; Fariña, J. M. \& Soto-Gamboa, M. Terrestrial birds living on marine environments: does dietary composition of Cinclodes nigrofumosus (Passeriformes: Furnariidae) predict their osmotic load? Rev. Chil. Hist. Nat., 76:335-43, 2003

Thiele, J. Handbuch der systematischen Weichtierkunde. Zweiter, Teil, 1929. p.778.

Vásquez, J. \& Vega, J. M. A. Ecosistemas marinos costeros del Parque Nacional Bosque Fray Jorge. In: Squeo, F. A.; Gutiérrez, J. R. \& Hernández, I. R. (Eds.). Historia Natural del Parque Nacional Bosque Fray Jorge. La Serena, Chile, Ediciones Universidad de La Serena, 2004. pp.23552 .

Wenz, W. Handbuch der palaozoologie. Vol. 6. Gastropoda, Teil 1: Allgemeiner Teil und Prosobranchia. Berlin, Gebrüder Borntraeger, 1938. p.1639.

Williams, S. T.; Karube, S. \& Ozawa, T. Molecular systematics of Vetigastropoda: Trochidae, Turbinidae and Trochoidea redefined. Zool. Scr., 37(5):483-506, 2008

Williams, S. T. \& Ozawa, T. Molecular phylogeny suggests polyphyly of both the turban shells (family Turbinidae) and the superfamily Trochoidea (Mollusca: Vetigastropoda). Mol. Phylogenet. Evol., 39(1):33-51, 2006.

Wood, W. Supplement to the index testaceologicus, or, A Catalogue of shells, British and foreign, arranged according to the Linnean system. London, W. Wood, 1828. p.59.

\section{Correspondence to:}

Dr. Gonzalo A. Collado

Facultad de Ciencias

Universidad de Chile

Received: 15-03-2012

Santiago

CHILE

Accepted: 11-04-2012

E-mail: g.collado@eudoramail.com 